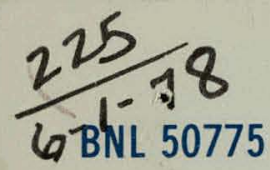

\title{
THE 1977 BREEDING BIRD CENSUSES AND VEGETATION SURVEYS IN TWO SUCCESSIONAL STAGES OF OAK-PINE FOREST
}

\author{
Gilbert S. Raynor, John J. Ruscica, James H. Clinton, \\ and David L. Larsen
}

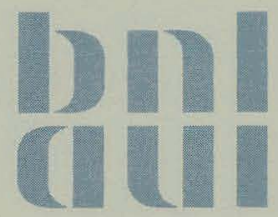

December 1977

BROOKHAVEN NATIONAL LABORATORY ASSOCIATED UNIVERSITIES, INC. UNDER CONTRACT NO. EY-76-C-02-0016 WITH THE UNITED STATES DEPARTMENT OF ENERGY 


\section{DISCLAIMER}

This report was prepared as an account of work sponsored by an agency of the United States Government. Neither the United States Government nor any agency Thereof, nor any of their employees, makes any warranty, express or implied, or assumes any legal liability or responsibility for the accuracy, completeness, or usefulness of any information, apparatus, product, or process disclosed, or represents that its use would not infringe privately owned rights. Reference herein to any specific commercial product, process, or service by trade name, trademark, manufacturer, or otherwise does not necessarily constitute or imply its endorsement, recommendation, or favoring by the United States Government or any agency thereof. The views and opinions of authors expressed herein do not necessarily state or reflect those of the United States Government or any agency thereof. 


\section{DISCLAIMER}

Portions of this document may be illegible in electronic image products. Images are produced from the best available original document. 


\title{
THE 1977 BREEDING BIRD CENSUSES AND VEGETATION SURVEYS IN TWO SUCCESSIONAL STAGES OF OAK-PINE FOREST
}

\author{
Gilbert S. Raynor, John J. Ruscica, James H. Clinton, \\ and David L. Larsen*
}

\section{December 1977}

*State University of New York at Stony Brook

BROOKHAVEN NATIONAL LABORATORY

ASSOCIATED UNIVERSITIES, INC.

UPTON, NEW YORK 11973 


\section{NOT I G E}

This report was prepared as an account of work sponsored by the United States Government. Neither the United States nor the United States Department of Energy (DOE), nor any of their employees, nor any of their contractors, subcontractors, or their employees, makes any warranty, express or implied, or assumes any legál liability or responsibility for the accuracy, completeness or usefulness of any information, apparatus, product or process disclosed, or represents that its use would not infringe privately owned rights.

Printed in the United States of America Available from

National Téchnical Information Service

U.S. Department of Commerce -5285 Port Royal Road.

Springfield, VA 22161 .

Price: Printed Copy $\$ 4.50$; Microfiche $\$ 3.00$

February 1978

330 copies 


\begin{abstract}
As part of a program to characterize the plant and animal life of the Laboratory site and surrounding areas, two breeding bird census plots were established in 1977 to document the occurrence and abundance of breeding species in two extreme successional stages of Long Island oak-pine forest. A 9.3-hectare plot located near the northeastern corner of the Laboratory site is composed of second growth oak-pine forest in a late successional stage. The second plot measures 9.7 hectares and is located in the scrub oak-pitch pine barrens at westhampton.

Each plot was surveyed with a transit and steel tape and marked with wooden stakes at 100 -foot intervals. Quantitative vegetational surveys were made in each plot and all plant species identified. Tree composition was measured as a function of species and size. Shrub density, percent of ground cover and percent of canopy were also measured. The Laboratory plot contained 2100 trees of five species per hectare, 72\% ground cover and $84 \%$ canopy coverage. The Westhampton plot contained only one tree species, Pitch Pine, at 366 trees per hectare, $92 \%$ ground cover and no canopy.
\end{abstract}

Twelve census trips, mostly of two to three hour duration, were made in each plot. Each bird observed was located on a scale map of the plot. At the end of the season, the number of territories was determined from the distribution of sightings. Eighteen territorial bird species were found in the Laboratory plot with between 479 and 629 territorial males per $\mathrm{km}^{2}$.. In Westhampton, only five breeding species were present. Density was between 312 and 374 males per $\mathrm{km}^{2}$. The Rufous-sided Towhee was the most common species in both plots. Future studies will document changes in both bird and plant species composition and abundance. 


\section{INTRODUCTION}

Two breeding bird census plots were established in 1977 to quantify the -occurrence and abundance of breeding species in representative Long Island habitats. One plot on Brookhaven National Laboratory property and another at -Westhampton were chosen to represent extreme stages of plant succession in oak-pine woodlands.

The plots were surveyed and marked by stakes prior to the breeding season. Censuses were conducted by repetitive trips during the breeding season. Occurrence, size, density, dominance and frequency of plant species were measured by plant surveys conducted during and after the breeding season. Methods followed were those suggested for the breeding bird censuses sponsored by the National Audubon Society (Ha11, 1946; Van Velzen, 1972). These censuses have been taken nationwide for 40 vears and are published annually in American Birds, formerly Audubon Field Notes.

DESCRIPTION OF BROOKHAVEN NATIONAL LABORATORY PLOT

The BNL census plot is located in the northeastern corner of the Laboratory property and is centered 700 feet south of the original north boundary and 2500 feet west of the original east boundary in a $1500 \times 1700$ foot tract of woods bordered on the east and west by firelanes, on the north by the boundary road and on the south by the north fence line of the radiation forest. The plot is about 6000 feet south of State Road 25, Middle Country Road or Jericho Turnpike, in Ridge. The center is about at $40^{\circ} 53^{\prime} 16^{\prime \prime}$ north latitude and $72^{\circ} 51^{\prime} 53^{\prime \prime}$ west longitude.

The plot is located in a second growth oak-pine forest (Figure 1) in a late stage of succession from scrub oak-pitch pine forest to climax oak forest. Previous history of the plot is unknown but it was probably cut from 50 to 70 years ago. Many of the oaks are arranged in tight groups indicating sprout growth from old stumps (Figure 2). No evidence of recent fire was noted. The forest is composed exclusively of White Oak (Ouercus alba), Scarlet Oak (Q. coccinia), Black Oak. (‥ velutina), and Pitch Pine (Pinus rigida) (Figure 3). Scientific names of plants are from Britton and Brown (1947). 


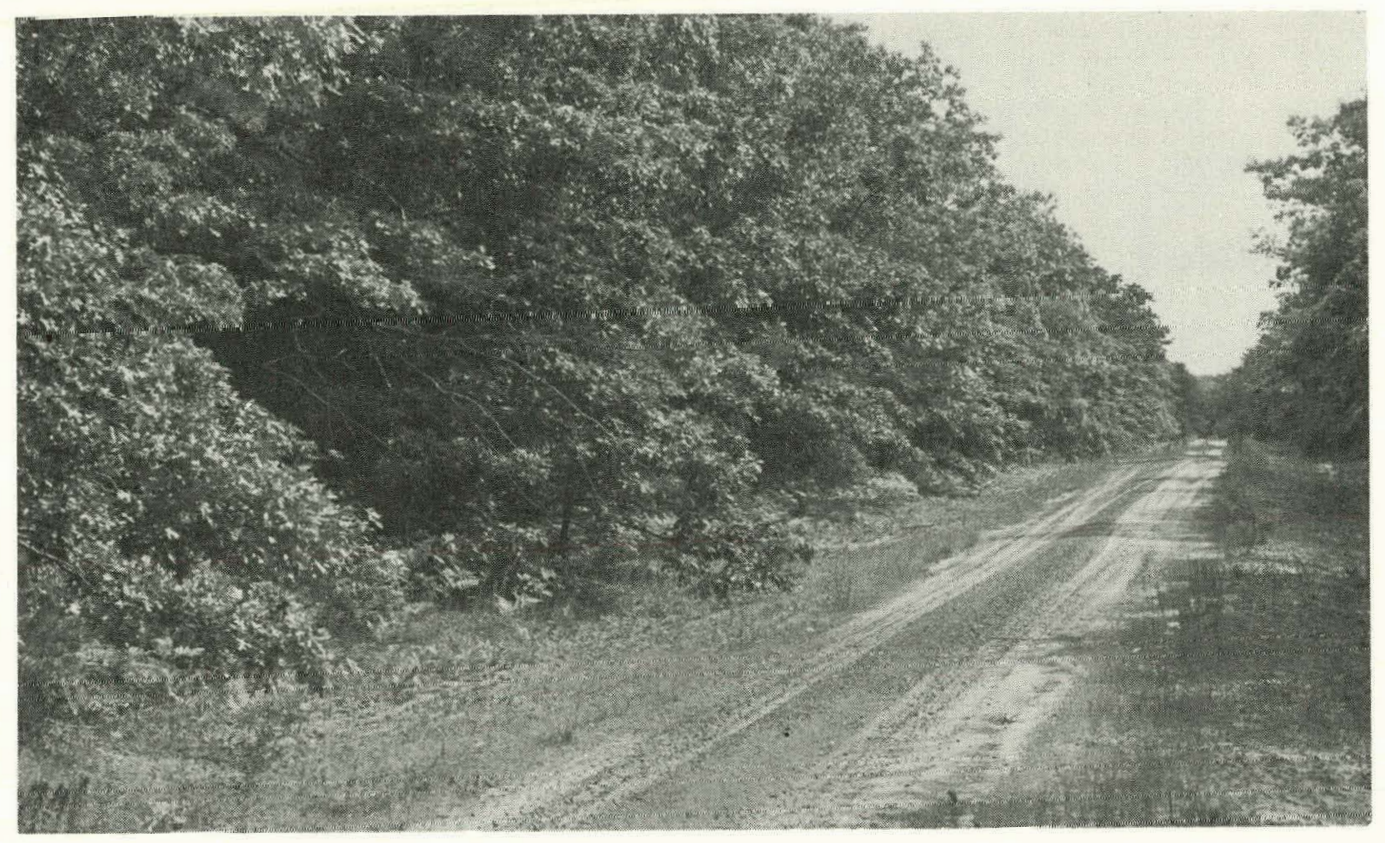

Figure 1. Western edge of forest containing BNL census plot.

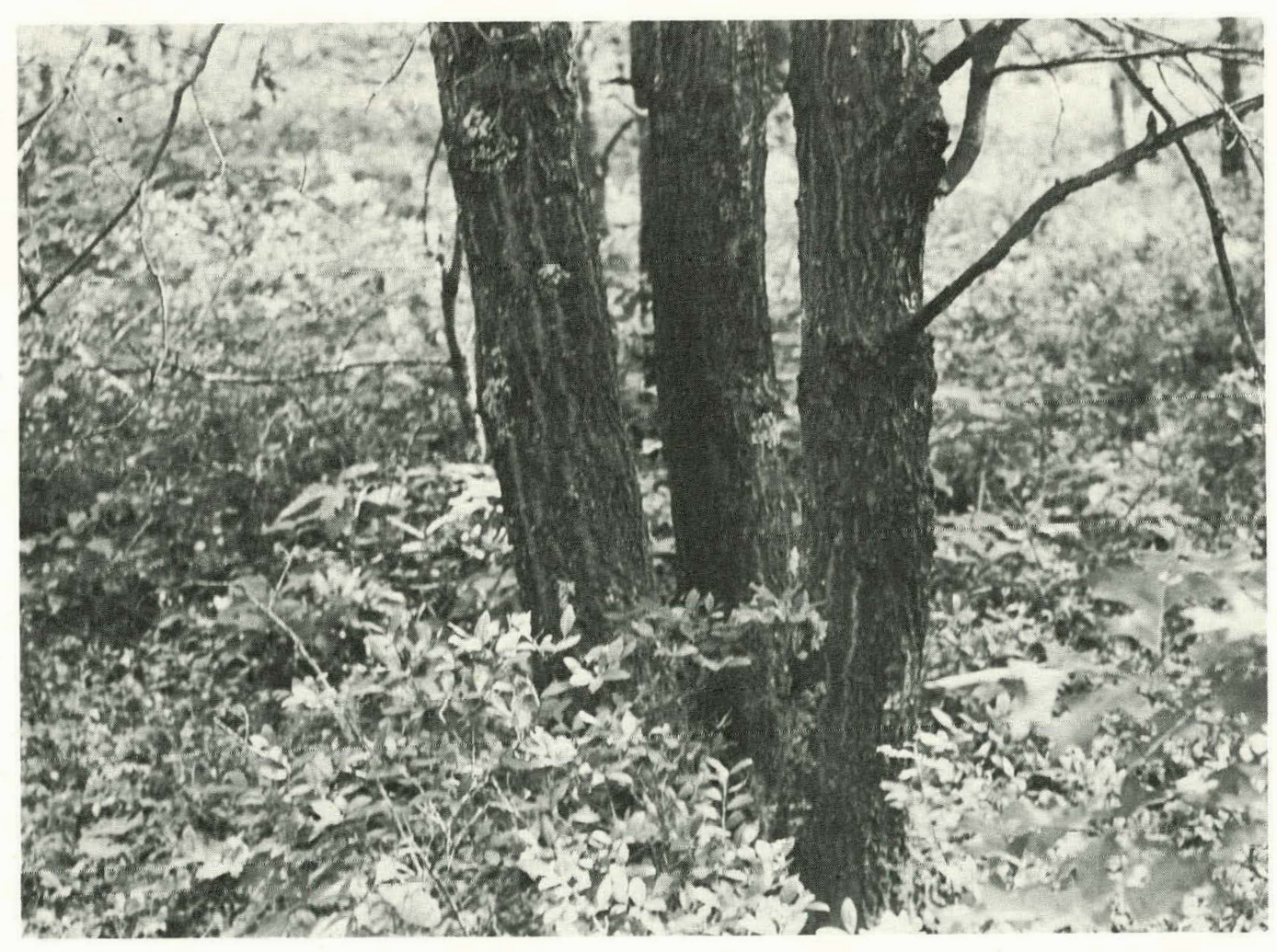

Figure 2. Sprout growth of Scarlet Oak in BNL plot. 


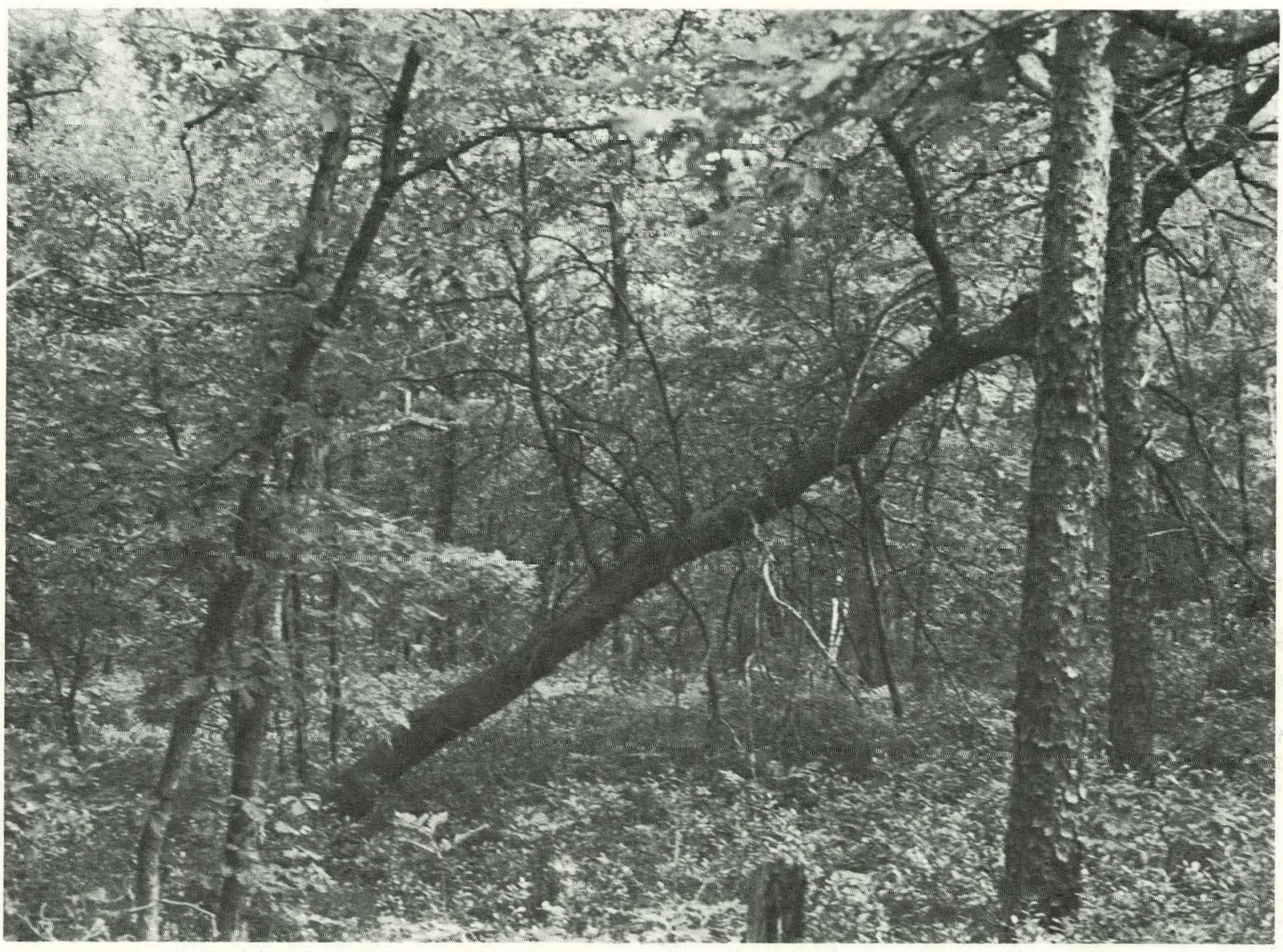

Figure 3. Interior of BNL plot. 
The plot lies between the Harbor Hill and Ronkonkoma moraines. The terrain is slightly rolling with one shallow valley through part of the plot. Elevation is about 80 feet above sea level. The soil is sandy and well drained and composed of Plymouth loamy sand, Riverhead sandy loam and Carver and Plymouth sands. No roads or trails penetrate the sampling grid which is bordered by at least 200 feet of similar vegetation on all sides. Soil types are from Warner et al. (1975).

The plot measures $1000 \times 1000$ feet $(304.9 \times 304.9 \mathrm{~m}$ ). It contains 22.96 acres or 9.29 hectares or $0.0929 \mathrm{~km}^{2}$. The plot was laid out with transit and steel tape and numbered wooden stakes placed at 100 foot-intervals.

A plant survey was conducted following methods described by James and Shugart (1970). Tree species size and composition were measured on ten randomly selected one-tenth acre plant survey plots. Composition in trees/acre is given in Table 1. Since over half of the trees were under 3.0 inches in diameter at 4.5 feet and $19 \%$ of the trees were dead, the data are presented in four sub-tables. Trees of all sizes, living and dead, total 850 /acre or $2100 /$ hectare. Living trees above 3.0 inches total 374 /acre or $924 /$ hectare. White Dak is the most numerous species followed by Scarlet Oak, Pitch Pine and Black nak. Average tree height is about 33 feet $(10 \mathrm{~m})$. Maximum oak height is 61 feet $(19 \mathrm{~m})$ and maximum pine height about 49 feet (15m).

Basal area by species in $\mathrm{ft}^{2} /$ acre and percent of total basal area is given in Table 2 for both plots and illustrated in Figure 4. Basal area in the BNL plot covers $0.127 \%$ of the 1 and area. The percentage frequency of basal area by size class is given in Table 3. At BNL, smal1 trees contribute most Lo total number and medium size trees most to total basal area (Figures 5 and 6).

Other measures of fores $t$ composition are given in Table 4. Relative density is the percentage of each species present. Relative dominance is the percentage of the total basal area contributed by each species. Frequency is the percentage of plant survey plots in which each species was found and is a measure of the eveness of distribution of each species.

The shrub layer (Figure 7) was sampled by Lwo transects across each of the ten plant survey plots. It is composed largely of saplings of the four tree species plus a minor amount of serub or Bear 0ak (0. ilicifolia). Shrubs reaching 4.5 feet totaled $290 /$ acre or $717 /$ hectare. If the trees under 3.0 inches are considered shrubs, the total is $717 /$ acre or $1772 /$ hectare. 
TABLEE 1

Tree Composition of BNL Plot

(Trees/ acre)

1a: Total Trees

\begin{tabular}{|c|c|c|c|c|c|c|}
\hline Species & $0-2.9^{\prime}$ & $3-5.9$ & $6-8.9$ & $9-14.9$ & Total & $\%$ \\
\hline Pitch Pine & 51 & 51. & 29 & 2 & 133 & 15.65 \\
\hline White Oak & 123 & 161 & $\epsilon$ & & 290 & 34.12 \\
\hline Scarlet Oak & 134 & 78 & 31 & 12 & 255 & 30.00 \\
\hline Biack Oak & 4 & 1 & 3 & & 8 & 0.94 \\
\hline Dead - & 115 & 49 & & . & 164 & 19.29 \\
\hline Total. & 427 & 340 & 69 & 14 & 850 & \\
\hline$\%$ & 50.24 & $\cdot 40.00$ & 8.12 & 1.65 & & . \\
\hline
\end{tabular}

1b. Trees $\geq 3.0$ in:

\begin{tabular}{lrrrrr} 
Species & $3-5.9$ & $6-8.9$ & $9-14.9$ & Total & \% \\
\hline Pitch Pine & 51 & 29 & 2 & 82 & 19.39 \\
White Oak & 161 & 6 & & 167 & 39.48 \\
Scarlet Oak & 78 & 31 & 12 & 121 & 28.61 \\
Black Dak & 1 & 3 & & 4 & 0.95 \\
Dead & 49 & 0 & & 49 & 11.58 \\
\hline Total & 340 & 69 & 14 & 423 & \\
$\%$ & 80.38 & 16.31 & 3.31 & &
\end{tabular}

1c. Total Living Trees

\begin{tabular}{lrrrrrr} 
Species & $0-2.9$ & $3-5.9$ & $6-8.9$ & $9-14.9$ & Total & $\%$ \\
\hline Pitch Pine & 51 & 51 & 29 & 2 & 133 & 19.39 \\
White Oak & 123 & 161 & 6 & & 290 & $42.27^{\circ}$ \\
Scarlet Oak & 134 & 78 & 31 & 12 & 255 & $37.17^{\circ}$ \\
Black Oak & 4 & 1 & 3 & & 8 & 1.17 \\
Total &, 312 & 291 & 69 & 14 & 686 & \\
$\%$ & 45.48 & 42.42 & 10.06 & 2.04 &
\end{tabular}

1d. Living Trees $\geq 3.0$ in.

\begin{tabular}{lrrrrr} 
Species & $3-5.9$ & $6-8.9$ & $9-14.9$ & Total & $\%$ \\
\hline Pitch Pine & 51 & 29 & 2 & 82 & 21.93 \\
White Oak & 161 & 6 & & 167 & 44.65 \\
Scarlet Oak & 78 & 31 & 12 & 121 & 32.35 \\
Black Oak & 1 & 3 & & 4 & 1.07 \\
\hline Total & 291 & 69 & 14 & 374 & \\
$\%$ & 77.81 & 18.45 & 3.74 & &
\end{tabular}


TABILE 2

Basal Area/Acre by Species

BNL

\begin{tabular}{|c|c|c|}
\hline Species & Area $\left(\mathrm{Ft} .^{2}\right)$ & $\%$ \\
\hline White Oak & $18.8^{1}$ & 34.07 \\
\hline Scarlet Oak & 16.61 & 30.08 \\
\hline Pitch Pine & 10.12 & 18.32 \\
\hline Dead & 9.02 & 16.33 \\
\hline Black nak & 0.66 & 1.19 \\
\hline
\end{tabular}

\section{WESTHAMPTON}

$\begin{array}{lll}\text { Species } & \frac{\left.\text { Area (Ft. }{ }^{2}\right)}{\text { Pitch Pine }} & \frac{\%}{3.93} \cdot \frac{100.00}{}\end{array}$

TABLE 3

Frequency of Percent nccurrence and Basal Area by Tree Diameter.

\begin{tabular}{|c|c|c|}
\hline & & BNL \\
\hline Dia. (in.) & $\%$ by size & $\%$ by basal area \\
\hline 0.5 & 14.1 & 2.3 \\
\hline $1.0^{\circ}$ & 5.6 & 1.8 \\
\hline 1.5 & 6.6 & 3.3 \\
\hline 2.0 & 11.3 & 7.4 \\
\hline 2.5 & .12 .7 & 10.5 \\
\hline 3.0 & 8.5 & 8.5 \\
\hline 3.5 & 11.0 & 12.8 \\
\hline 4.0 & 7.1 & 9.4 \\
\hline 4.5 & 6.8 & 9.9 \\
\hline 5.0 & 3.1 & 5.1 \\
\hline 5.5 & 2.5 & 4.5 \\
\hline 6.0 & 2.4 & $4: 7$ \\
\hline 6.5 & 1.3 & 2.8 \\
\hline 7.0 & 1.9 & 4.7 \\
\hline 7.5 & 2.1 & 3.0 \\
\hline 8.0 & 0.5 & 1.3 \\
\hline 8.5 & 1.0 & 2.7 \\
\hline 9.0 & 0.5 & 6.3 \\
\hline 9.5 & 0.2 & 7.5 \\
\hline 10.0 & 0.1 & 3.9 \\
\hline 10.5 & 0.4 & 1.2 \\
\hline 11.0 & 0.2 & 0.9 \\
\hline 11.5 & 0.1 & 0.5 \\
\hline 12.0 & 0.1 & 0.9 \\
\hline
\end{tabular}

WESTHAMPTON

$\%$ by size \% by basal area

$8.3 \quad 2.2$

$25.0 \quad 13.3$

$17.7 \quad .14 .2$

$17.7 \quad 18.9$

$11.5 \quad 15.3$

$10.4 \quad 16.7$

$4.2 \quad 7.8$

$\begin{array}{ll}4.2 & 8.8\end{array}$

$1.0 \quad 2.8$ 


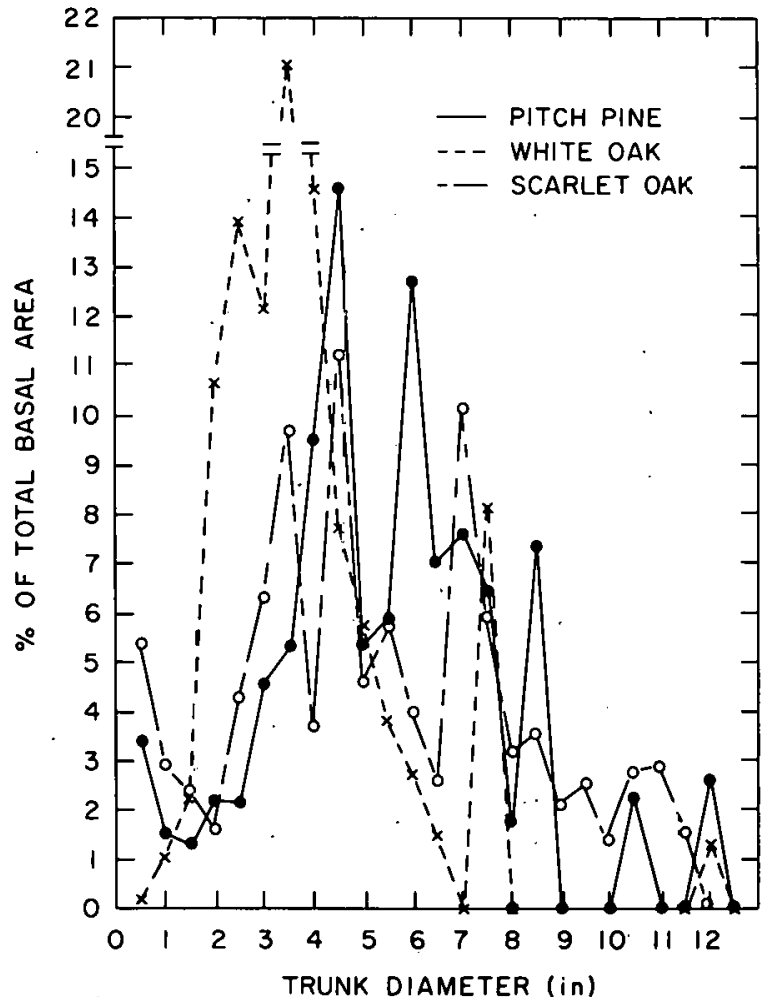

Fígure 4. Percent of basal area of trees in BNL plot by trunk diameter for three species.

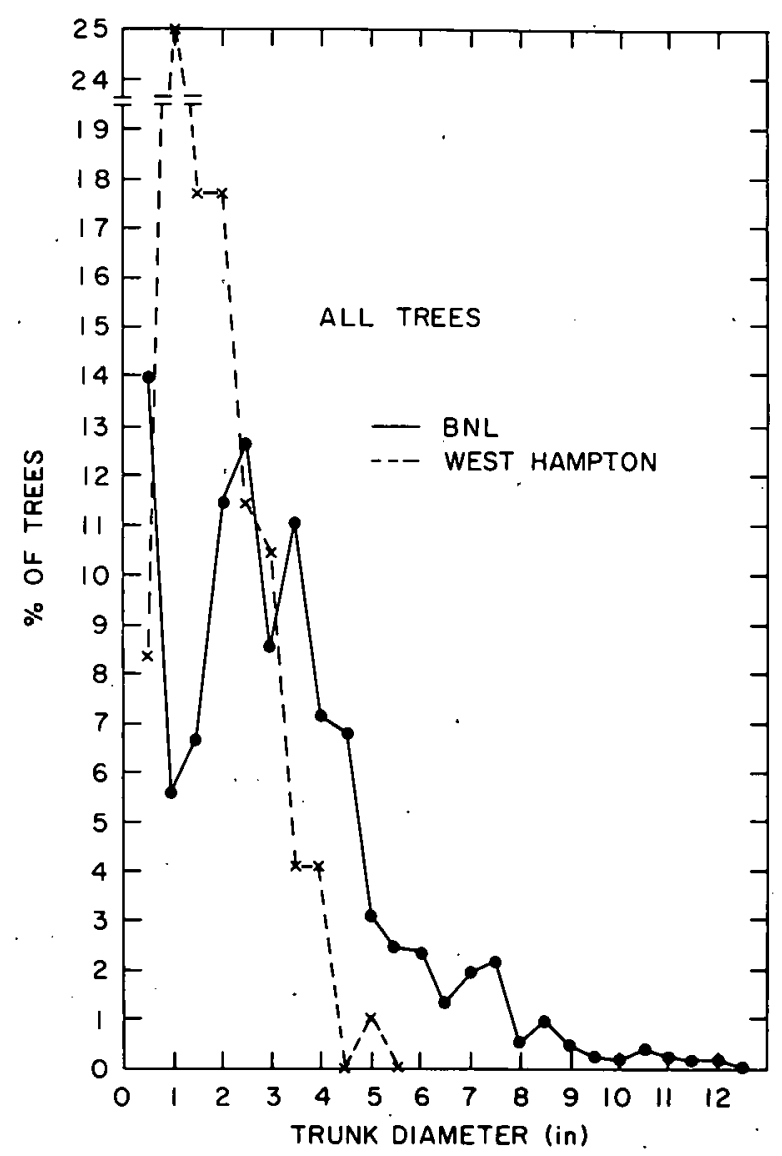

Figure 5. Frequency distribution of all trees in BNL and Westhampton plots by trunk diameter. 


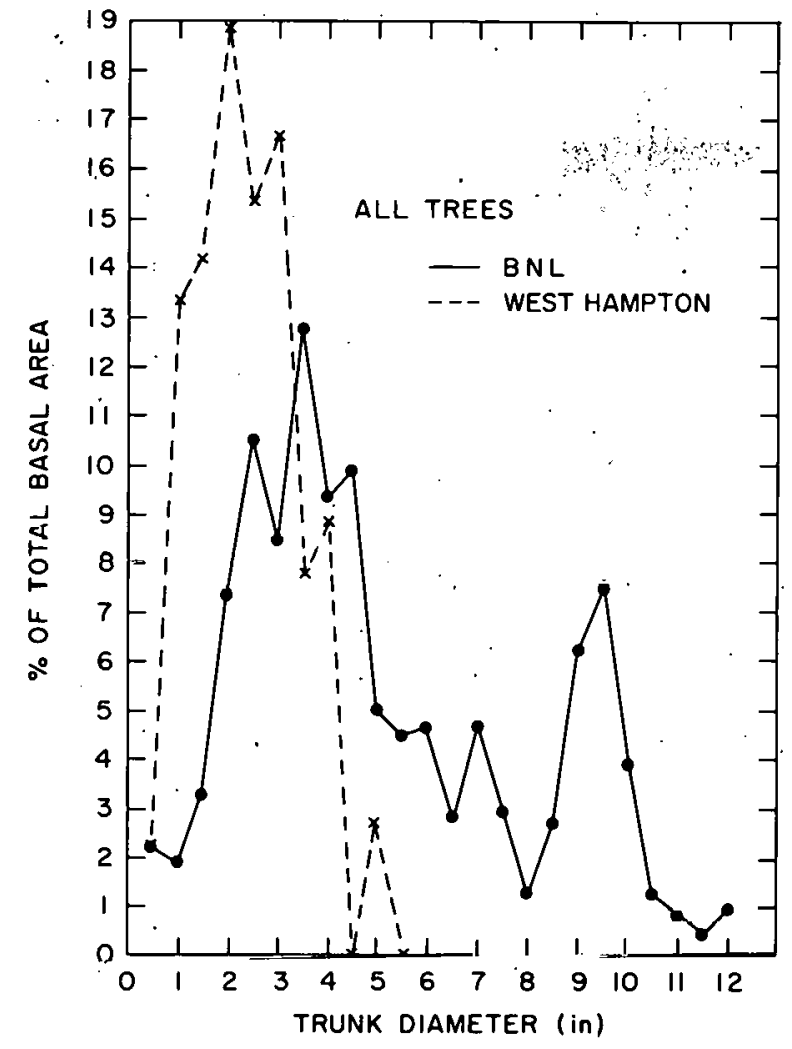

Figure 6 . Fieyuellicy distribution of all trees in $\overline{B N}$ and Weothampton plots by basal area. 


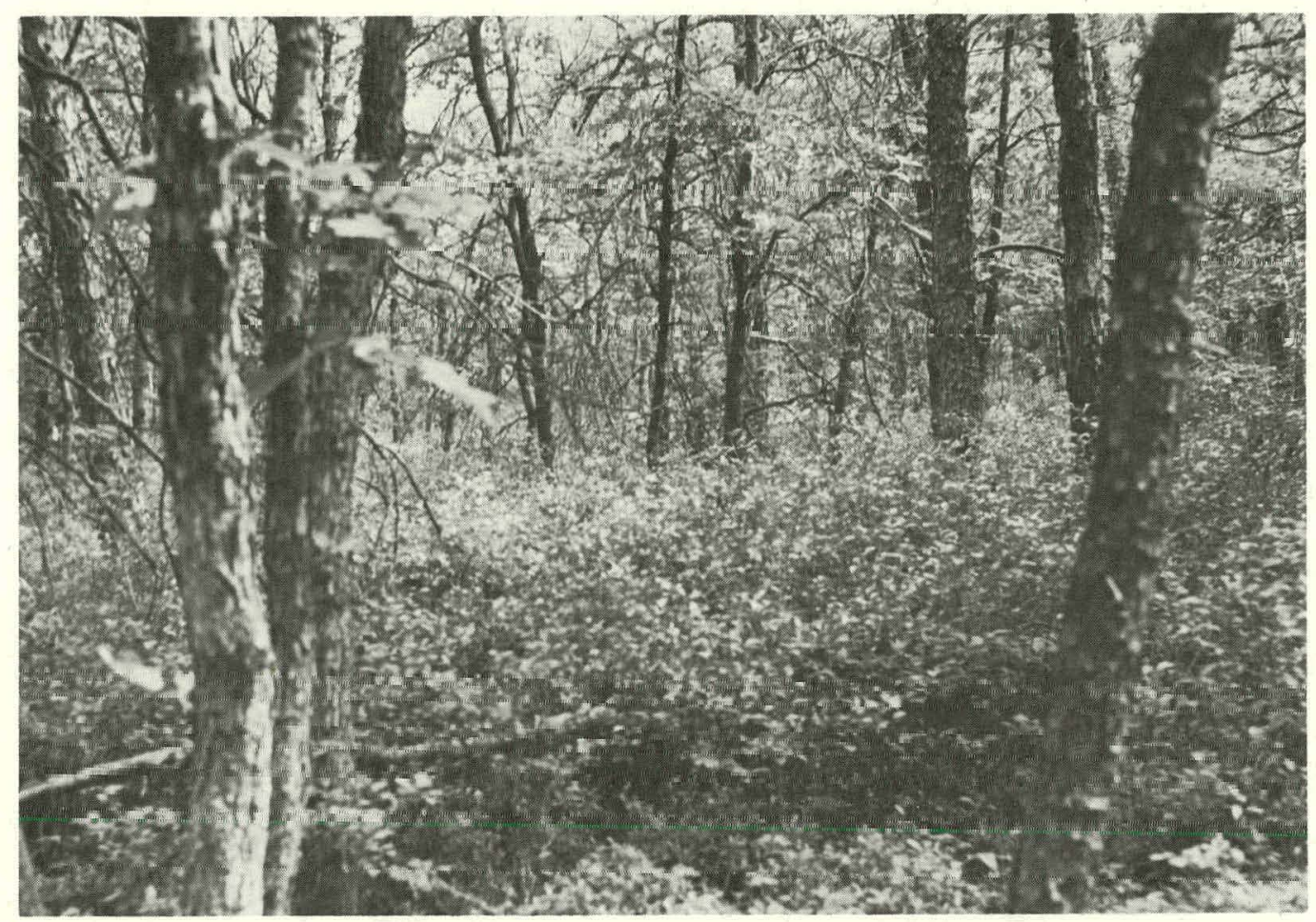

Figure 7. Shrub layer and undergrowth in BNL plot.

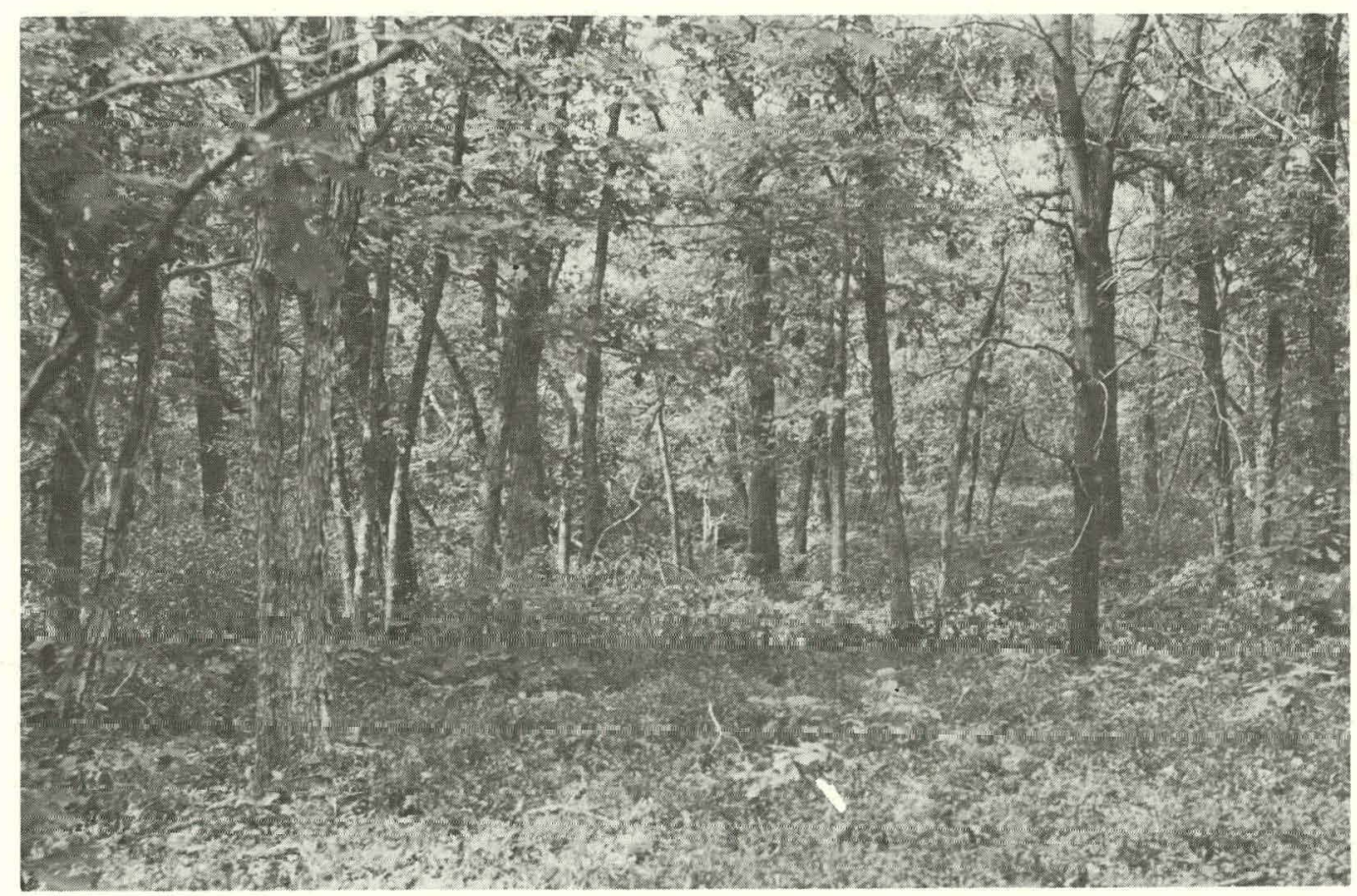

Figure 8. Lower shrub layer in BNL plot. 
A lower shrub layer (Figure 8) is included in ground cover and is composed of Black Huckleberry (Gaylussacia baccata), Late Blueberry (Vaccinium vacillans), Scrub Chestnut Oak (‥prinoides), Low Blueberry (V. pennsylvanicum), and smaller amounts of Sweet Fern (Myrica asplenifolia), Bayberry (M. caroliriensis) Stagger Bush (Lyonia mariana). Most are from one to three feet tall. One or two vines of Greenbrier (Smilax sp.) were noted.

Herbaceous plants were scattered throughout in the more open areas and include Bracken Fern (Pteridium aquilinum), (Figure 9), Goat's Rue (Tephrosia virginiana), Wild Indigo (Baptisia tinctoria), Spreading Dogbane ( Apocynum androsaemifolium), Cow Wheat (Melampyrum lineare), Wintergreen (Gaultheria procumbens), Panic Grass (Panicum sp.) and Pennsylvania Sedge (Carex pennsylvanica). The Bracken, Wintergreen and Sedge were the only species reasonably common and generally distributed.

Based on twenty-four equally spaced measurements along the transects across each plant survey plot, ground cover was found in $72.1 \%$ of the area.

Based on similar measurements, canopy is present above $83.8 \%$ of the area (Figure 10).

The plot is surrounded by similar habitat on all sides so no edge effect occurs.

\section{DESCRIPTION OF WESTHAMPTON PLOT}

The Westhampton census plot is located in the northern portion of Westhampton about 0.6 miles south of New York State Route 27 (Sunrise Highway) and about 0.9 miles west of County Road 31 (01d Riverhead Road) and about opposite the northern portion of Suffolk County Airfield (formerly Suffolk County Air Force Base). The center is near $40^{\circ} 51^{\prime} 23^{\prime \prime}$ north latitude and $72^{\circ} 39^{\prime} 46^{\prime \prime}$ west 1ongitude.

The plot is located in a representative section of the Dwarf Pine Plains or Pitch Pine-Scrub Oak barrens which cover a large area in this region (Figure 11). This habitat is characterized by scattered dwarfed Pitch Pines and scattered to dense thickets of Scrub oak. In contrast to other pine barrens on tong Island which eventually revert to climax oak forest if protected from fire and cutting, larger oaks such as White and Scarlet, are absent. Thus, this plant community apparently constitutes a climax type maintained primarily by poor soil and severe local climatic conditions and secondarily by fire. However, the study plot has not been burned for many years and the pine plains have reportedly existed with little change since colonial days, 


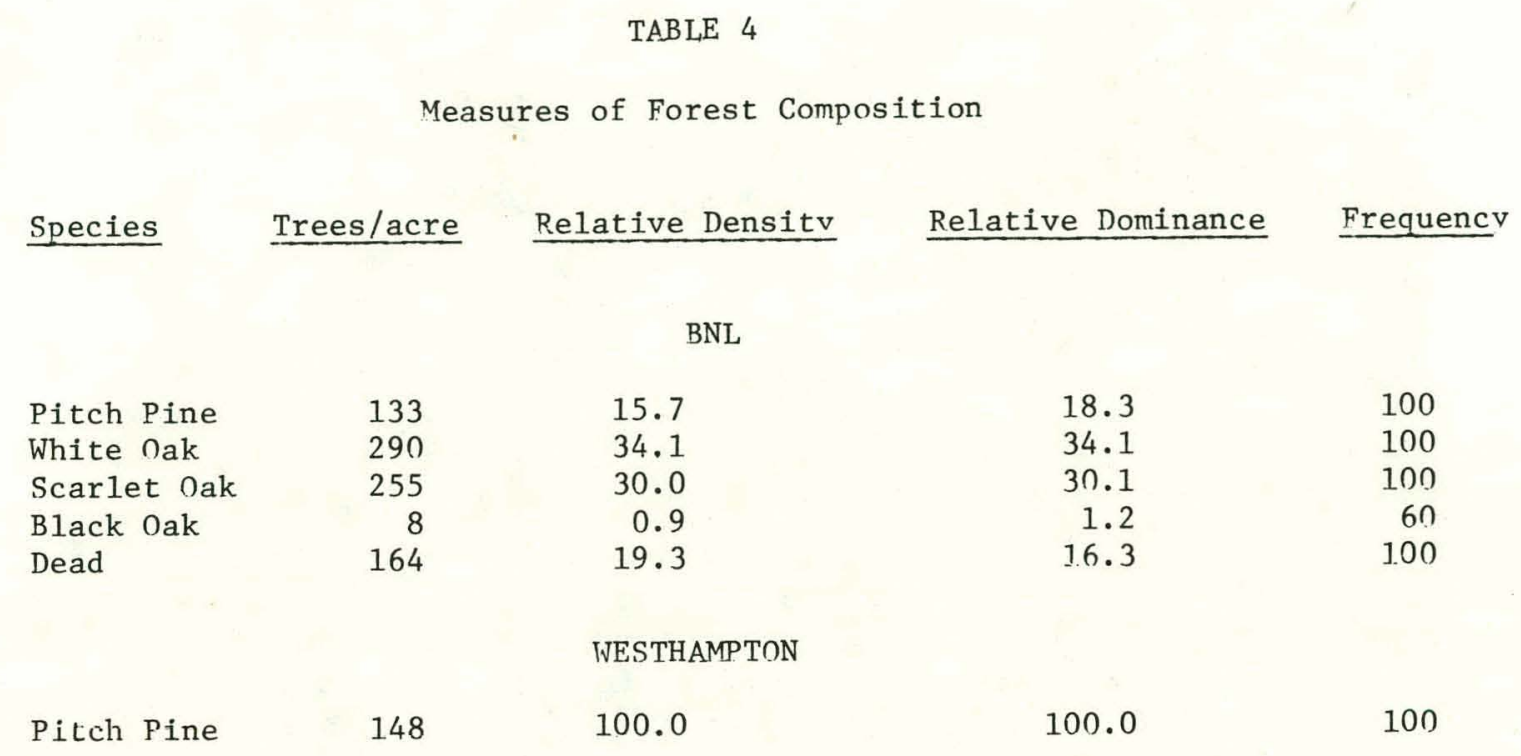

TABLE 5

Size Composition of Pitch Pines on Westhampton P1ot (Trees/acre)

$\begin{array}{lrrrrr}\text { Dia. at } 4.5 \mathrm{ft} \text {. (in.) } & \underline{0-2.9} & & 3.0-5.9 & <4.5 \mathrm{ft} . & \text { Total } \\ \begin{array}{l}\text { Count } \\ \%\end{array} & 80 & 20 & 48 & 148 \\ \% \geq 4.5 \mathrm{ft} . & 80.1 & 13.5 & 32.4 & \\ & & 20.0 & & \end{array}$




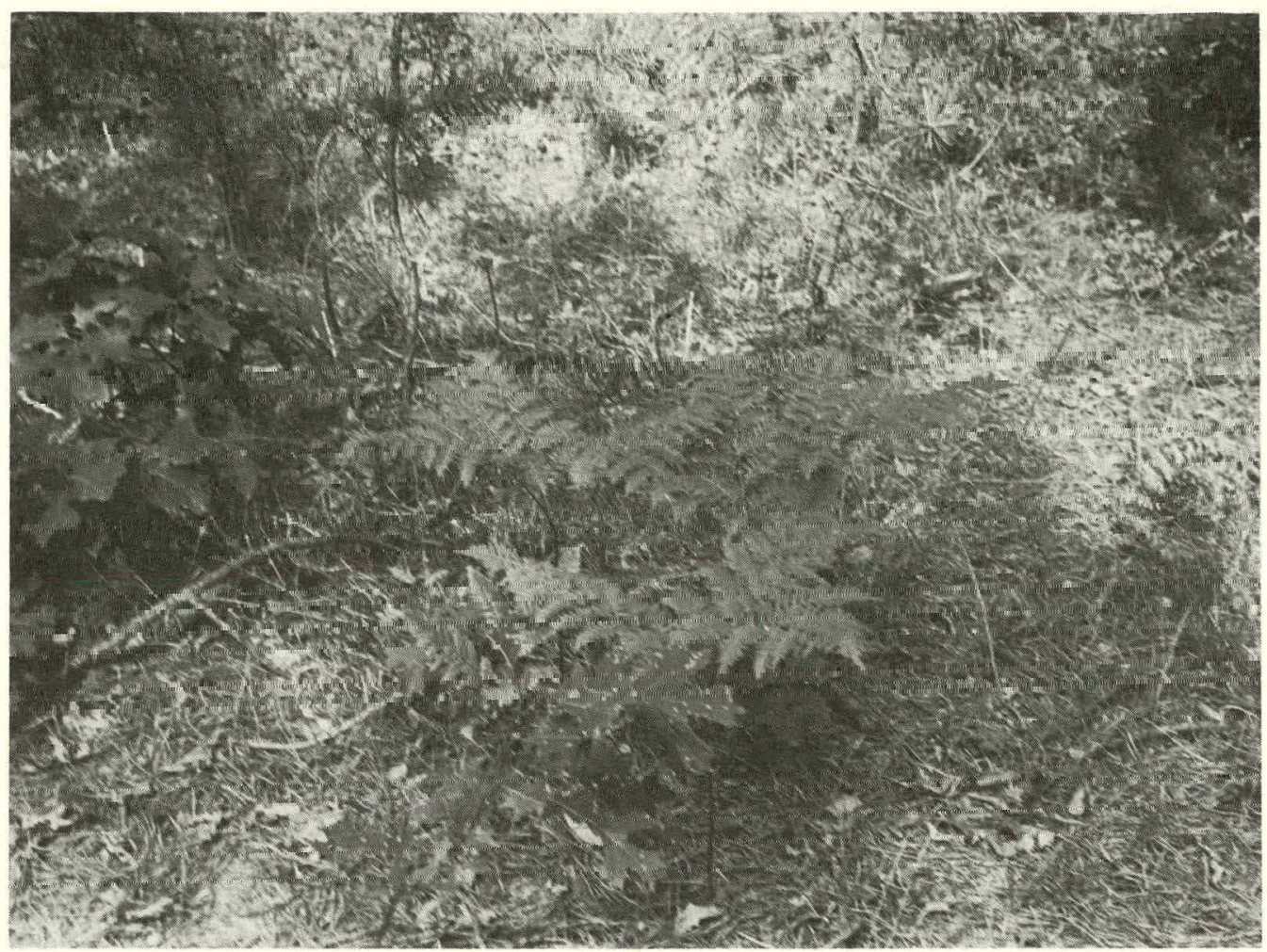

Figure 9. Bracken fern and undergrowth in BNL plot.

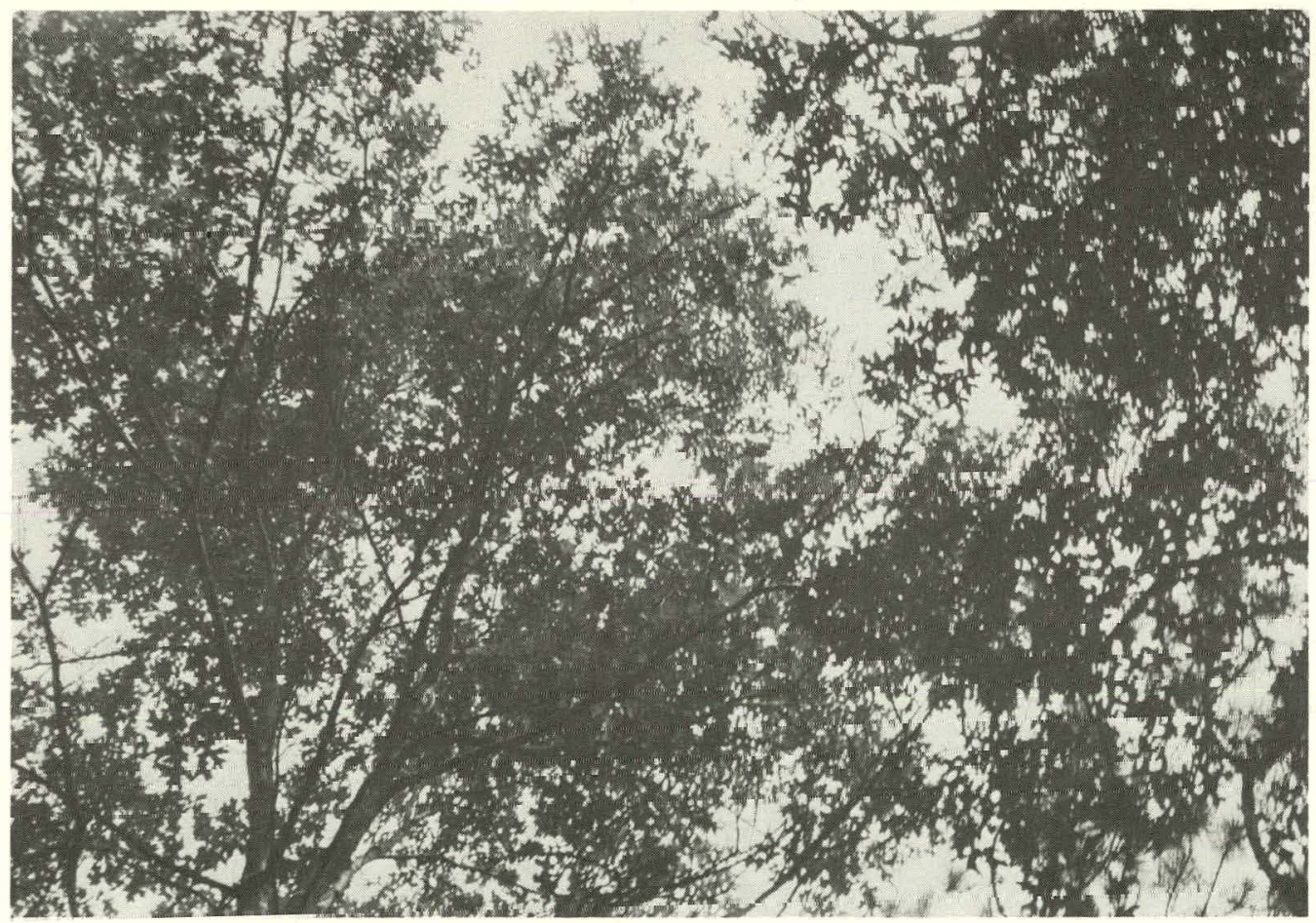

Figure 10. Deciduous canopy in BNL plot. 


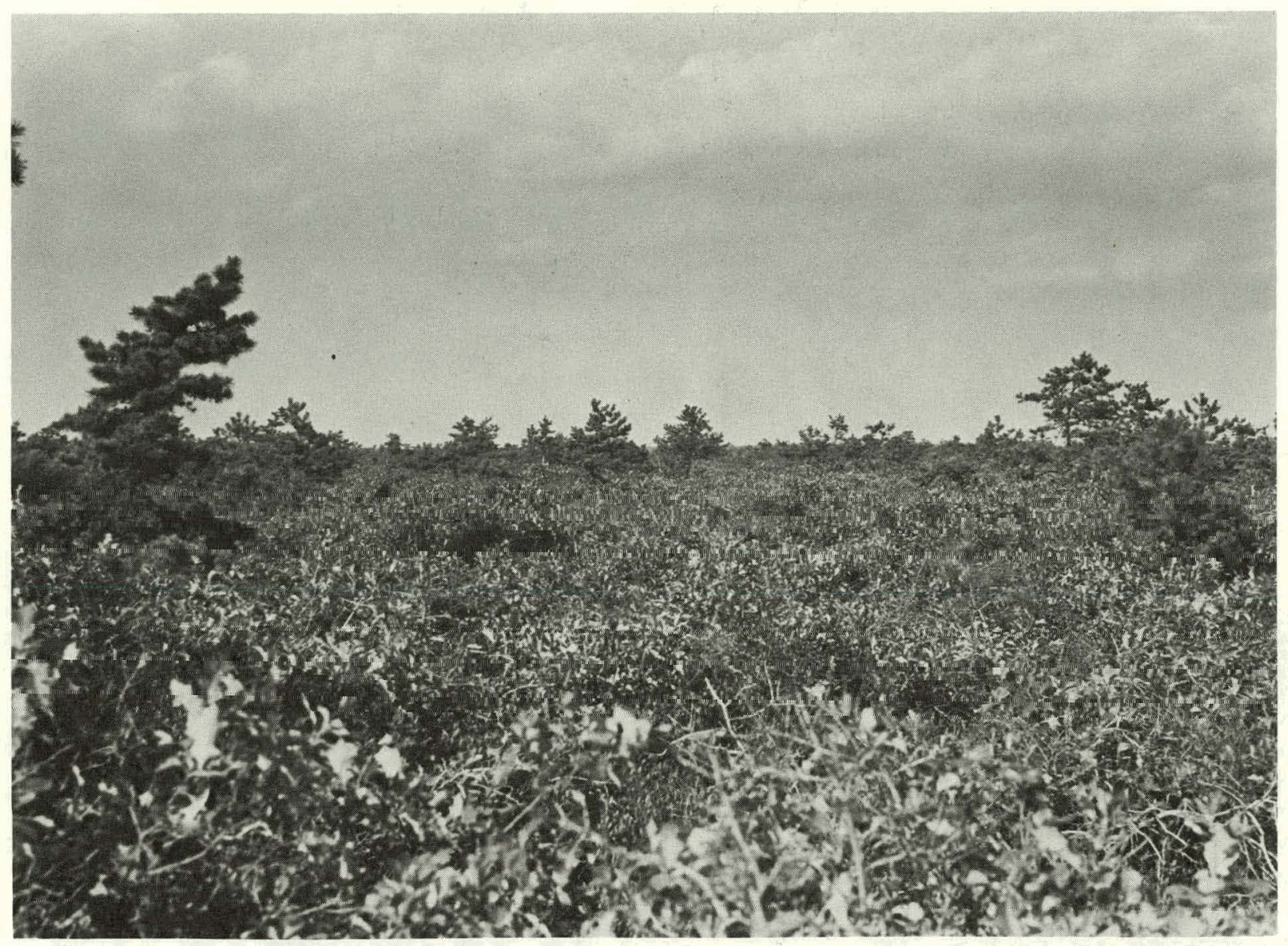

Figure 11. Westhampton pitch pine-scrub oak barrens. 


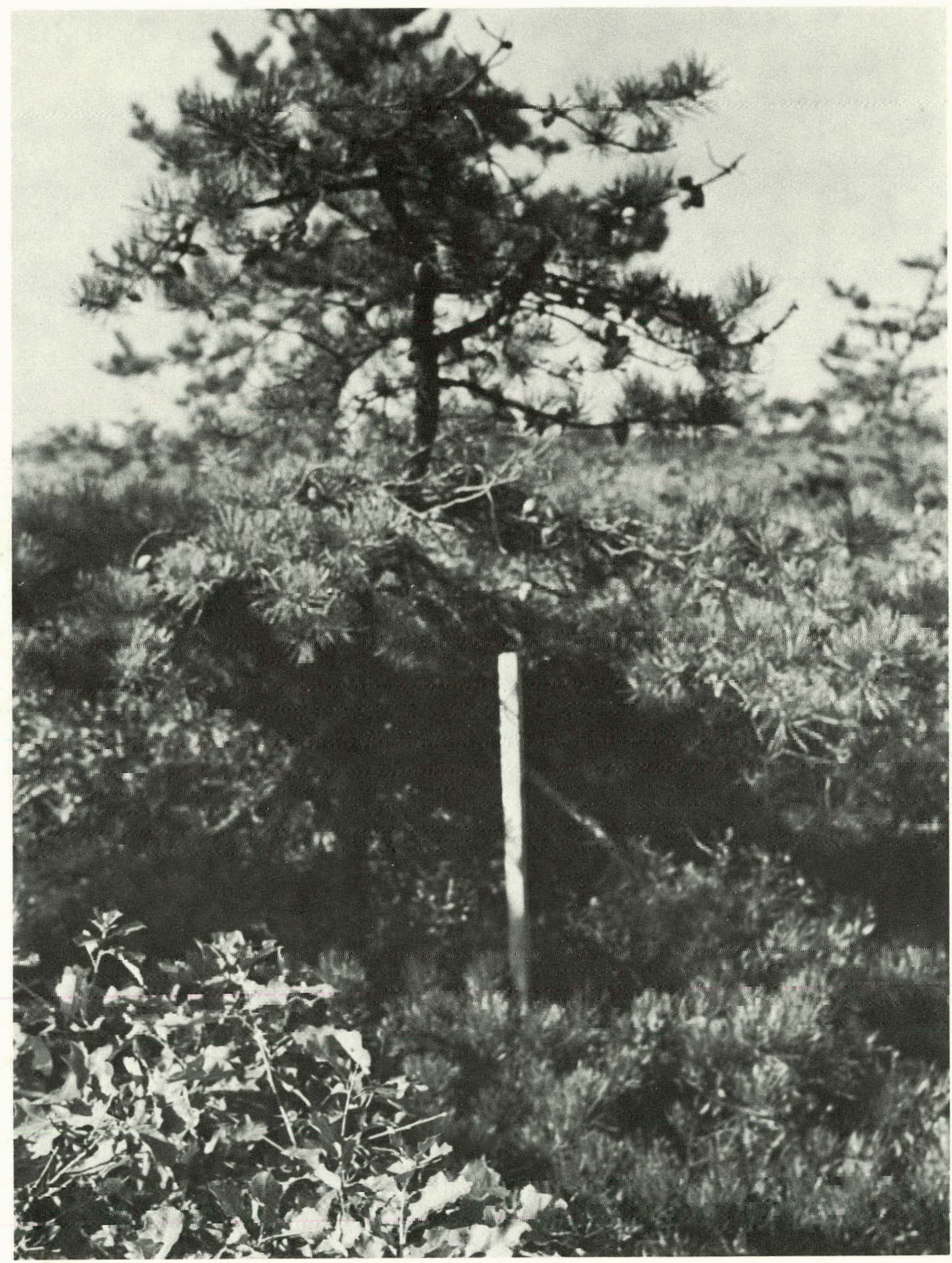

Figure 12. Pitch pine and grid stake in Westhampton plot. 
The plot is in the upper portion of the glacial outwash plain south of the Ronkonkoma moraine. Elevation is about 80 feet above sea level and the terrain is somewhat rolling. The extremely sandy and well-drained soil is composed of Carver and Plymouth sands and Plymouth loamy sand. A seldom-used dirt and cinder road provides access to the vicinity of the plot but no roads or trails penetrate the sampling area.

The plot measures $800 \times 1300$ feet $(244 \times 396 \mathrm{~m})$ with the 1 ong axis approximate1y NNE-SSW. It contains 23.8 acres or 9.67 hectares or $0.0967 \mathrm{Km}^{2}$. The plot was laid out with transit and steel tape and numbered wooden stakes placed at 100-foot intervals.

As in the surrounding region, the vegetation is dominated by Pitch Pine and Scrub Oak. The pine (Figure 12) is the only tree species and is rather scattered except in the northwestern sector of the plot where a rather dense stand occurs. Extrapolated from counts on ten randomly chosen one-tenth acre plant survey plots, there are 148 Pitch Pines/acre (366/hectare) of which 100/acre (247/hectare) are over 4.5 feet tall. The size distribution is given in Table 5 which shows that $80 \%$ are less than 3 inches in diameter at 4.5 feet and all are less than 6 inches in diameter. Most frequent tree height is 6-8 feet $(1.8-2.4 \mathrm{~m})$ and maximum 20 feet $(5.1 \mathrm{~m})$.

Basal area covers on $1 y 0.009 \%$ of the land area (Table 2). A percentage frequency by size and basal area is given in Table 3 and illustrated in Figures 5 and 6 . As at BNL, small sizes dominate the number frequency and somewhat larger trees the basal area frequency. Values of relative density, relative dominance and frequency are all 100\% for the Pitch Pine (Table 4).

Scrub Oak is the sole species in the dominant shrub layer (Figure 13) and the number of stems/acre was estimated from counts along two transects across each of the ten plant survey plots. Density is 10,100 stems/acre or 24,975 stems/hectare. Most Scrub Oaks are from three to four feet tall with some to five feet and others lower.

A lower shrub layer (Figure 14) from one to two feet tall is included in the ground cover and is composed largely of Black Huckleberry and Late Blueberry with smaller numbers of Low Blueberry. The Huckleberry is most numerous. A few plants of Stagger Bush and Sweet Fern are also present.

True ground cover is predominantly Bear Berry (Arctostaphvlos Uva-ursi) (Figure 15) which covers nearly all areas not too shaded by trees and shrubs. 


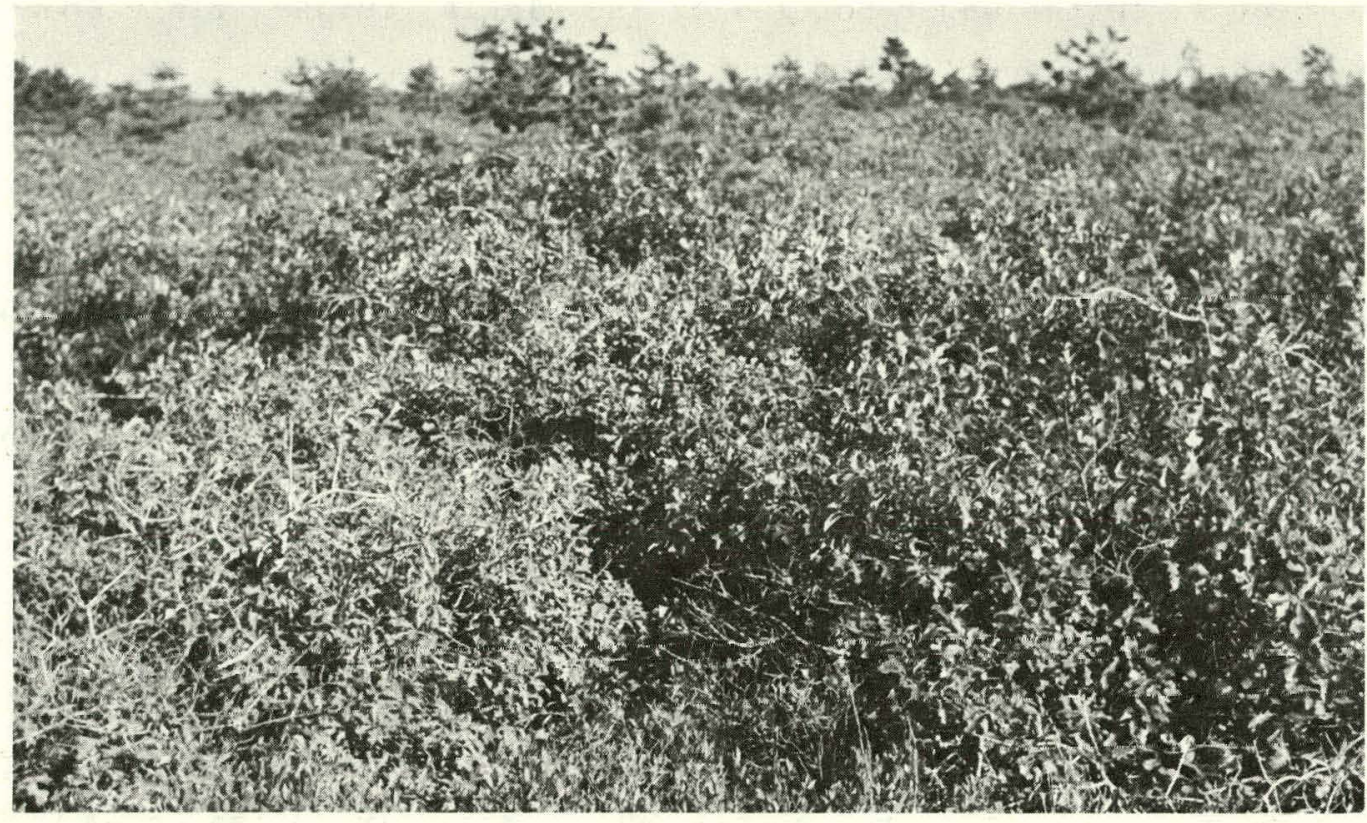

Figure 13. Scrub oak thicket in Westhampton plot.

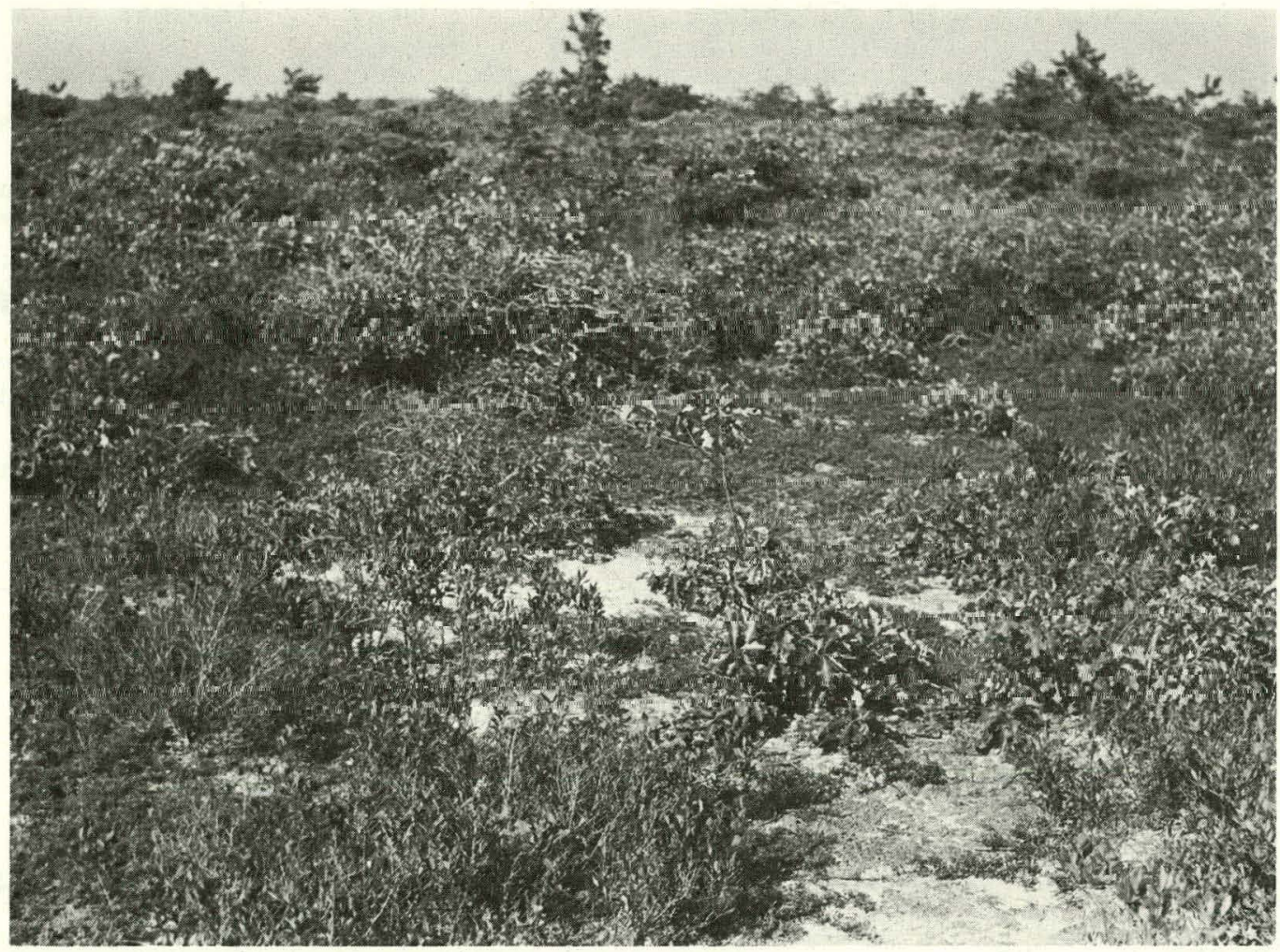

Figure 14. Lower shrub layer and ground cover in Westhampton plot. 
TABLE 6

Description of Census Trips

BNL

\begin{tabular}{|c|c|c|c|c|c|}
\hline \multirow[b]{2}{*}{ Date } & \multirow[b]{2}{*}{ Time (EST) } & \multicolumn{2}{|c|}{ Wind } & \multirow[b]{2}{*}{ Temp. $\left({ }^{O} F\right)$} & \multirow[b]{2}{*}{ Weather } \\
\hline & & Speed & Dir. & & \\
\hline May 24 & $0600-0800$ & 2 & SW & 64 & Scattered Cirrus, Haze \\
\hline May 26 & 0600-0900 & 2 & $\mathrm{~N}$ & 64 & Clear \\
\hline June 1 & $0600-0800$ & 3 & SSE & 58 & Overcast Altostratus \& Stratus \\
\hline June 8 & $0600-0830$ & 6 & W & 52 & Scattered Cirrus \\
\hline June 14 & $0515-0810$ & 1 & Var. & 58 & Broken Cirrus \\
\hline June 16 & $0600-0900$ & 2 & $\mathrm{NE}$ & 64 & Broken Cirrus \\
\hline June 26 & $1330-1630$ & 3 & $\mathrm{~N}$ & 78 & Scattered-Broken Cumulus \\
\hline June 28 & $0400-0700$ & 2 & SW & 65 & Not recorded \\
\hline July 2 & $1320-1540$ & 8 & NW & 80 & Broken Altocumulus \\
\hline July 7 & $2100-2115$ & 2 & ESE & 70 & Overcast Stratocumulus \\
\hline Ju1y 11 & $0600-0800$ & 1 & SE & 65 & Broken-Scattered Stratocumulus \\
\hline July 27 & $0600-0800$ & 2 & NE & 66 & Clear \\
\hline
\end{tabular}

WESTHAMPTON

\begin{tabular}{|c|c|c|c|c|c|}
\hline \multirow[b]{2}{*}{ Date } & \multirow[b]{2}{*}{ Time (EST) } & \multicolumn{2}{|c|}{ Wind } & \multirow[b]{2}{*}{ Temp. $\left({ }^{\mathrm{O}} \mathrm{F}\right)$} & \multirow[b]{2}{*}{ Weather } \\
\hline & & Speed & Dir. & & \\
\hline May 22 & $0635-0845$ & 2 & SW & 66 & Scattered Cumulus \\
\hline May 24 & $0435-0735$ & 2 & SW & 64 & Fog-Broken Cirrus \\
\hline June 1 & $0425-0735$ & 3 & SSE & 58 & $\begin{array}{l}\text { Overcast Altostratus \& Strato- } \\
\text { cumulus }\end{array}$ \\
\hline June 5 & $0600-1000$ & 1 & W & 62 & Overcast Altostratus \\
\hline June 12 & $0600-0830$ & 3 & NW & 68 & Broken Stratocumulus \\
\hline June 17 & $0400-0700$ & 2 & $\mathrm{~S}$ & 63 & Clear-Overcast Stratus \& Fog \\
\hline June 23 & $0400-0710$ & 1 & $\mathrm{~N}$ & 64 & Clear \\
\hline June 26 & $1200-1300$ & 5 & $\mathrm{~N}$ & 78 & Overcast Cumulus-Rainshower \\
\hline July 2 & $0600-0900$ & 2 & W & 76 & Broken Altocumulus \& Stratocumulus \\
\hline July 10 & $0715-1030$ & 2 & NE & 75 & Clear \\
\hline July 14 & $0355-0615$ & 2 & NW & 67 & Clear \\
\hline July 16 & $0700-0845$ & 3 & WSW & 85 & Scattered Cirrus \\
\hline
\end{tabular}


A moderate amount of Heath-1ike Hudsonia (Hudsonia ericoides) and a few plants of Woolly Hudsonia ( $\underline{H}$. tomentosa) are also present.

Herbaceous plants are scattered thinly throughout in the more open areas and include Goat's Rue, Wild Indigo, Downy Goldenrod (Solidago puberula), Toothed White-topped Aster (Seriocarpus asteroides), Low Show Aster (Aster spectabilis), Poverty Grass (Aristila dichotoma) and Panic Grass.

Based on twenty-four equally spaced spot measurements along two transects across each plant survey plot, ground cover is present in $96.7 \%$ of the census tract. No true canopy is present.

The plot is surrounded by similar habitat on all sides although the pines are taller and denser west of the plot than $n$ the nther three sides. Thus, no edge effect is present.

\section{CENSUS COVERAGF:}

Coverage of the two plots is detailed in Table 6 which also lists weather conditions. Weather data were taken from BNL records modified by observations at Westhampton during the census visits. Wind speed and direction are from the 37 foot-level on Ace Tower. Temperature is the average for the census period and is taken at the instrument shelter near the Meteorology Building.

Most trips were made in early morning when song was at its peak. One evening trip was made at BNL to census nocturnal species. During most censis trips, the observer travelled along alternate rows but deviated from this track when necessary to locate specific birds. The location of all birds seen or heard was plotted on a gridded map of the plot with appropriate notations for sex, song, territorial conflict or other pertinent observations. A separate map was used for each trip. In general, on alternate trips, traverses across the plot were made at right angles to the direction used on the previous trip to equalize temporal coverage of all sections. Visitors, species not breeding in the plot, and species flying over the plot were also noted.

\section{ANALYSIS}

At the end of the season, a master map was prepared for each species showing the location of all sight or sound encounters with accompanying information. From these maps, the number of territorial males was estimated by the clustering of encounters, by locations of two or more males observed simultaneously and by the location of territorial conflicts. For some species, it was not possible to separate the data into an exact number of territories. 
TABLE 7

Species Comnosition and Density of Territorial Males on BNL P1ot

\begin{tabular}{lrrrr} 
Species & Territorial males & No. $/ \mathrm{Km}^{2}$ & & No./100 Acres \\
\cline { 2 - 2 } Rufous-sided Towhee & $15.5-17.5$ & $167-188$ & $68-77$ \\
Ovenbird & $7-9$ & $75-97$ & $31-40$ \\
Blue Jay & $3-7$ & $32-75$ & $13-31$ \\
Black \& White Warbler & 3 & 32 & 13 \\
Baltimore Oriole & 3 & 32 & 13 \\
Crested Flycatcher & $2-4$ & $22-43$ & $9-18$ \\
Wood Thrush & 2 & 22 & 9 \\
Whip-poor-will & $1-3$ & $11-32$ & $4-13$ \\
Yellowthroat & $1-2$ & $11-22$ & $4-9$ \\
Scarlet Tanager & $1-2$ & $11-22$ & $4-9$ \\
Downy Woodpecker & 1 & 4 & 11 \\
Black-capped Chickadee & 1 & 4 & 11 \\
White-breasted Nuthatch & 1 & 4 & 11 \\
Brown Thrasher & 1 & 4 & 11 \\
Hermit Thrush & 1 & 4 & 11 \\
Pine Warbler & 1 & 4 & 11 \\
Yellow-shafted Flicker & 1 & - & - \\
Tufted Titmouse & 1 & - & - \\
& & & $196-257$
\end{tabular}

TABLE 8

Species Composition and Density of Territorial Males on Westhampton Plot

\begin{tabular}{|c|c|c|c|}
\hline Species & Territorial Males & No. $/ \mathrm{Km}^{2}$ & No. $/ 100$ Acres \\
\hline Rufous-sided Towhee & $13 \cdot 5-16 \cdot 5$ & $138-169$ & $57-69$ \\
\hline Prairie Warbler & $1 n$ & 102 & 42 \\
\hline Field Sparrow & 3.5 & $4 ?$ & 15 \\
\hline Yellowthroat & $2-4$ & $21-4]$ & $8-17$ \\
\hline Brown Thrasher & $1.5-2.5$ & $15-26$ & $6-11$ \\
\hline Total & $30-38$ & $312-374$ & $128-1.53$ \\
\hline
\end{tabular}




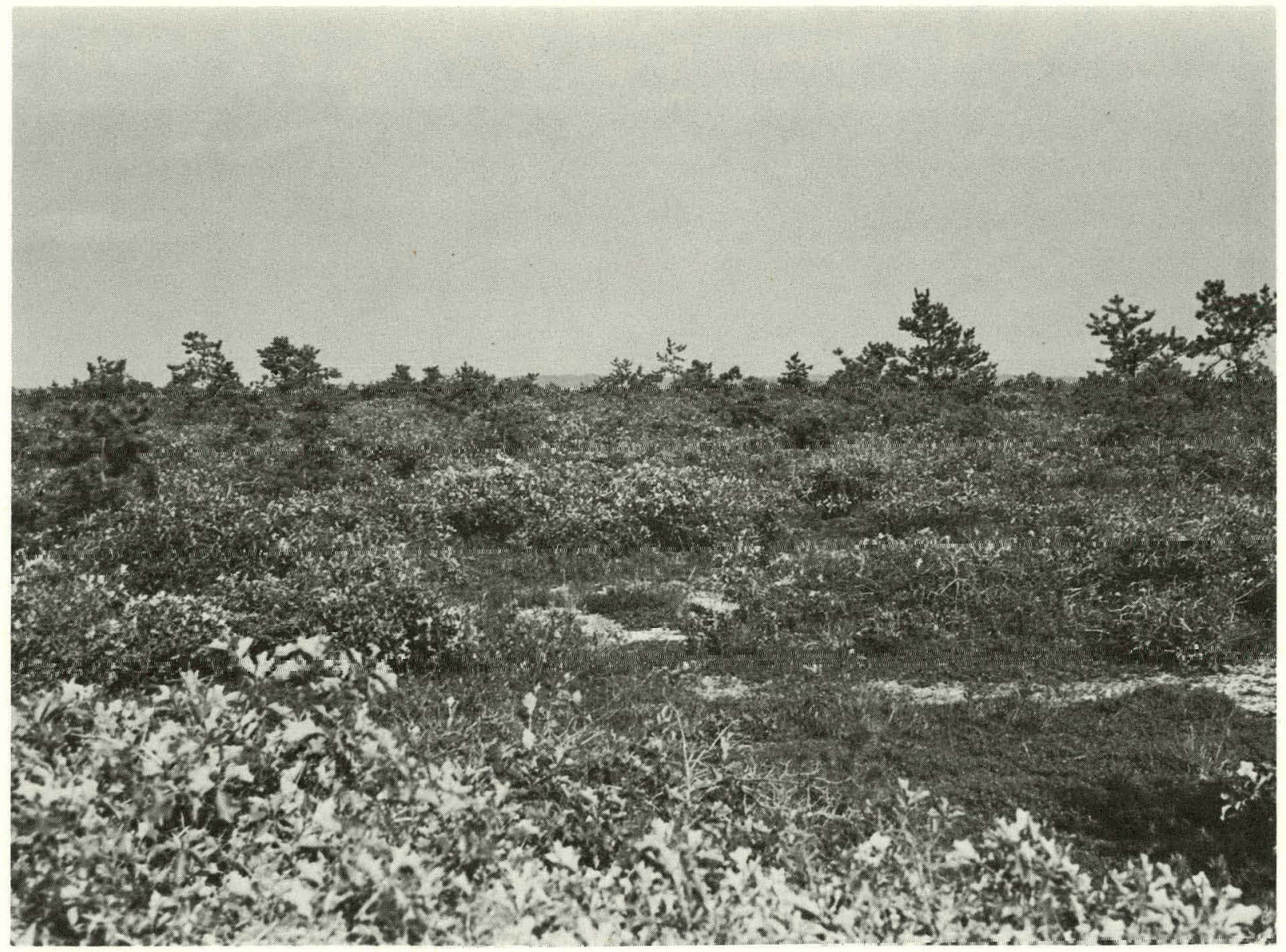

Figure 15. Mats of bear berry in open area of Westhampton plot. 
In these cases, a range of probable values was assigned.

BNL CENSUS

A list of the 18 territorial species on the BNL plot with number of territorial males, number/Km2 and number/100 acres is given in Table 7 . Scientific names of species mentioned in this report are given in the appendix. Rufous-sided Towhees were the dominant species and Ovenbirds the second most abundant. Eight species were represented by only one o.r a partial territory. The Towhee, Brown Thrasher, Hermit Thrush and Yellowthroat are species found in earlier stages of oak-pine forest succession. Most of the other species are more typical of more mature forest. Two species found at Westhampton; Prairie Warbler and Field Sparrow, are no longer found in the BNL plot. On the other hand, the stand has apparently not matured enough to attract one of our most common breeding species in mature forests, the Red-eyed Vireo.

Visiting species observed on the BNL plot include Yellow-billed Cuckoo, Hairy Woodpecker, Mockingbird, Robin, Red-eyed Vireo, Blue-winged Warbler, Common Grackle and Brown-headed Cowbird. Species observed flying over were Mourning Dove, Common Crow, Fish Crow and American Goldfinch. All species observed nest at BNL or in nearby areas.

\section{WESTHAMPTON CENSUS}

A 1 ist of the five territorial species found at Westhampton is given in Table 8 with number of territorial males, number/ $\mathrm{Km}^{2}$ and number/100 acres. Here also, the Towhee is dominant but number per unit area is smaller than at BNL probably reflecting the more imporerished habitat and sparser vegetation. The Prairie Warbler is confined to the earlier stages of oak-pine forests and finds ideal habitat here.

Visitors to the plot include Marsh Hawk, Mourning Dove, Yellow-billed Cuckoo, Black-billed Cuckoo, Great Horned Owl, Chimney Swift, Eastern Kingbird, Wood Pewee, Tree Swallow, Barn Swallow; Purple Martin,. Blue Jay, Black-capped Chickadee; Mockingbird, Robin, Blue-winged Warbler, Redwinged Blackbird, Common Grark1e, Brnwn-headed Cowbird, American Goldfinch and Vesper Sparrow. Al1 probab1y nested nearby except the Swift and the Swallows which were seen feeding over the plot and mày have nested some distance away. The Vesper Sparrow held a territory just east of the plot. Probable nearby nesters 
observed flying over the plot were Common and Fish Crow. Species not nesting locally but seen flying over were Common Loon, Osprey and Herring full.

\section{DISCUSSTON}

Only a few breeding bird censuses have previously been taken on Long Island and none in upland habitats. However, similar oak-pine woods have been censused in New Jersey and Massachusetts and are available for comparison.

In 1972, for instance, census 43 in the. New Jersey pine barrens reported ten species with 356 pairs $/ \mathrm{Km}^{2}$. The Towhee was most numerous and other species occurred only in small numbers (Van Velzen, 1973).

In 1976, a recently burned pine-oak forest of 22.5 hectares in eastern Massachusetts, census 55 , yielded 220 pairs $/ \mathrm{Km}^{2}$ with 20 species. Ovenbird and Towhee were most numerous.. A nearby Scrub Oak-Pitch Pine forest of 7.5 hectares, census 58 , found 500 pairs $/ \mathrm{Km}^{2}$ of 22 species with Towhee and Prairie Warbler dominant. Thus our results are similar to those found elsewhere in comparable habitat but obviously reflect specific local conditions.

\section{FUTURE PLANS}

The two plots will be censused again in 1978. If additional help is obtained, one or more new plots may be added: A long term goal is to document the breeding bird distribution and density of all remaining native habitats on Long Island and to monitor their changes with time.

\section{REFERENCES}

Britton, N.L. and A. Brown, 1947. An illustrated flora of the northern United States, Canada and the British possessions, 2nd ed., 3 vol. New York, New York Botanical Garden.

Ha11, G.S., 1946, Breeding-Bird Censuses-Why and How. Audubon Field Notes, $18: 413-416$.

James, F.C. and H.H. Shugart, Jr., 1970. A Quantitative Method of Habitat Description. Audubon Field Notes, 24:727-736. 
Van Velzen, W.T., 1972. Breeding-Bird Census Instructions: American Birds, $26: 927-931$

Van Velzen, W.T. (ed.), 1973. Thirty-seventh Breeding-Bird Census. American Birds, 27:955-1019.

Van Velzen, W.T. (ed.), 1977. Fortieth Breeding-Bird Census. American Birds, 31:24-93.

Warner, J. W., W. E. Hanna, R. J. Handry, J. P. Wulforst, J. A. Neelev, R. L. Holmes and C. E. Rice, 1975. Soil survey of Suffolk County, New York. U. S. Dept. of Agriculture, Soil Conservation Service," Washington, n.C., $101 p p+100$ maps. 
APPENDIX .

Scientific Names of Birds Recorded

Common Name
Common Loon
Marsh Hawk
Osprey
Herring Gull
Mourning Dovg
Yellow-billed Cuckoo
Black-billed Cuckoo
Great Horned Owl
Whip-poor-w1l1
Chimney Swift
Hairy Woodpecker
Downy Woodpecker
Eastern Kingbird
Great Crested Flycatcher
Eastern Wood Pewee
Tree Swallow
Barn Swallow
Purple Martin
Blue Jay
Common Crow
Fish Crow
Black-capped Chickadee
Tufted Titmouse
White-breasted Nuthatch
Mockingbird
Brown Thrasher
Robin
Wood Thrush
Hermit Thrush
Red-eyed Vireo
Black and White Warbler
Blue-winged Warbler
Pine Warbler
Prairie Warbler
Ovenbird
Yellowthroat
Redwinged Blackbird
Common Grackle
Brown-headed Cowbird
Scarlet T'anager
American Goldfinch
Rufous-sided Towhee
Vesper.Sparrow
Field Sparrow

\author{
Scientific Name \\ Gavia immer \\ Circus cyaneus. \\ Pandion haliaetus \\ Larus argentatus \\ Zenaidura macroura. \\ Coccyzus americanus \\ Coccyzus erythropthalmus \\ Bubo virginianus \\ Caprinulgus voctferus \\ Chaetura pelagica \\ Dendrocopus villosus \\ Dendrocopus pubescens \\ Tyrannus tyrannus \\ Myiarchus crinitus \\ Contopus virens \\ Iridoprocne bicolor \\ Hirundo rustica \\ Progne subis \\ Cyanocitta cristata \\ Corvus brachyrhynchus \\ Corvus ossifragus \\ Parus atricapillus \\ Parus bicolor \\ Sitta carolinensis \\ Mimus polyglottos \\ Toxostoma rufum \\ Turdus migratorius \\ Hylocichla mustelina \\ Hylocichla guttata \\ Vireo olivaceus \\ Mniotilta varia \\ Vermivora pinus \\ Dendroịca pinus \\ Dendroica discolor \\ Seiurus aurocapillus \\ Geoth 1ypis trichis \\ Agelaius phoeniceus \\ Ouiscalus quiscula \\ Molothrus ater \\ Piranga-olivacea \\ Spinus tristis \\ Pipilo erythrophthalmus \\ Pooecetes gramineus \\ Spizella pusilla
}

